\title{
Case Study of Teacher Training for Project STEM Course
}

\author{
Shu Han ${ }^{1}$, Rongzhao Hong ${ }^{2}$, Xin $\mathrm{An}^{1}$, Yushun $\mathrm{Li}^{1}$ \\ ${ }^{1}$ Digital learning and education public service engineering research center of the Ministry of Education, Beijing Normal \\ University, Beijing, China \\ ${ }^{2}$ School of Education, Taiwan Normal University, Taiwan, China \\ Correspondence: Yushun Li, Digital learning and education public service engineering research center of the Ministry of \\ Education, Beijing Normal University, Beijing, China.
}

Received: August 3, 2020

doi:10.11114/jets.v8i10.4956
Accepted: August 27, 2020

Online Published: August 31, 2020

URL: https://doi.org/10.11114/jets.v8i10.4956

\begin{abstract}
Educators are paying more attention to students' hands-on ability with critical thinking which has not been emphasized in previous Chinese education system. To fill this gap, there is a need to organize a hands-on workshop to develop teachers' STEM hands-on skills to promote on high school campus. Therefore, the purposes of this study are: 1. exploring the development status of teachers' hands-on ability after ending the workshop and 2. exploring the effectiveness of the project-based STEM training with interdisciplinary concept content compared with the traditional STEM training. Based on the two-day teacher training of STEM workshop, this paper used Flanders interaction analysis which is an observation technique used to record and analyze the process and impact of teacher-student interaction in the classroom. Through the analysis, we found that the learners were active in this training course, the interaction between teachers and learners was very frequent, and the relationship between them was quite consistent (harmonious). Then we inferred the training effect of the teachers in the training by combining the works or results submitted by the learners after the workshop. The error rate of these exercises or results was low, indicating that peer discussion or group discussion played an important role in the process of practice. Compared with the traditional iFIAS method, it can be found that in the training based on the project-based teaching model, learners' advanced cognitive abilities such as analysis and synthesis were developed, and their knowledge transfer ability was more flexible, which was also a reflection of interdisciplinary ability.
\end{abstract}

Keywords: PBL, interdisciplinary, STEM courses, iFIAS, teacher training

\section{Introduction}

"STEM" is an acronym for the discipline of Science, Technology, Engineering and Mathematics. STEM education and teaching has got increasing attention in recent years $(\mathrm{Hu}, \mathrm{Yeh}, \&$ Chen, 2020) as the growth of demand for innovative future-oriented talents in 21 century (Conradty, Sotiriou, \& Bogner, 2020). STEM was first proposed in the United States as a strategy to cultivate students' knowledge and accomplishment in science, technology, engineering, mathematics, cultivate talents in science and engineering (Honey, Pearson, \& Schweingruber, 2014), and improve global competitiveness (Hu et al., 2020). Nowadays, many countries continue to use STEM, which has developed into STEAM or STEM+ with more subjects. The connotation of STEM is mainly the cultivation of students' interdisciplinary ability. But, in the current curriculum, STEM education is usually implemented to teach students from elementary school to college, and few STEM courses are specifically applied to teacher training, teachers have not experience to develop such ability, thus, that is a need to conduct an exemplary workshop to develop teachers' competence to implement i-STEM courses. Teachers need to develop their subject skills, especially STEM teachers who have profound science and engineering literacy, interdisciplinary ability and problem-solving ability. Earlier research findings show that training activities in continuing teacher education can be key for better implementation (Steffen, Janis, Rainer, \& Christoph, 2016).

New educational policies have also emphasized on hands-on skills for students to learn STEM, for example, the maker education abroad and the craftsman spirit at home. However, in the current educational phenomenon, only visual and audio practice in lecture-oriented teaching, seldom hands-on course for Kinect learning style students can be benefited. Thus STEM with handson practice should be promoted to fulfill the new educational policies. To solve this insufficiency, the present study designed a workshop whose main content is interdisciplinary knowledge of programming, making small machine objects and designing the Internet of Things. Such interdisciplinary learning is designed to cultivate teachers' competencies of i-STEM with hands-on ability. How the effect of workshop were explored in relation to teachers' interdisciplinary ability and practical ability. 
A trans-disciplinary curriculum is free from the constraints of subject-matter boundaries and is therefore life-centered, contextual, and practically limitless (Drake, 1993); (Nicolescu, 1997). The curriculum is designed through a non-linear, system-oriented process, grounded in constructivist and complexity theories, and marked by open-ended planning and freedom for teachers and students to meet the challenges of spontaneity and contextuality (Levin, 1999). We mainly pay attention to the training content in the workshop, selection and design of STEM education is not a science, technology, engineering and mathematics simple superposition of four disciplines, but to make them effective integration between each other, and form into an organic whole. As a typical form of interdisciplinary education, the core value of STEM education lies in not only retaining the characteristics of each discipline, but also enabling these disciplines to flexibly integrate and promote the development of each discipline. The existing PBL project-style learning design lacks the consideration of interdisciplinary content, which makes students lack the cultivation of their comprehensive thinking when solving practical problems (Dong \& He, 2019). Therefore, we focus on the selection of interdisciplinary concept content for training, in order to pay attention to the development of teachers' ability after this training.

There is little research to design workshops to explore the teachers' interdisciplinary ability and practical ability. Thus, the purposes of this study are to:

1.explore the changes of teachers' hands-on ability after ending the workshop.

2.explore the effectiveness of the project-based STEM training with interdisciplinary concept content compared with the traditional STEM training.

\section{Literature Review}

\section{A. The necessity of STEM teacher training and the selection of interdisciplinary content}

In the process of learning and promoting STEM, many problems have gradually emerged. For example, how to integrate interdisciplinary courses, how to design STEM courses, and the shortage of highly qualified STEM educators (Schmidt \& Fulton, 2016), etc. Teachers play important roles in implementing STEM education successfully (Khuyen, Van Bien, Lin, Lin, \& Chang, 2020). For the shortage of STEM teachers, many scholars call for that there is a tremendous need for research in the K-12 context related to the implementation of such technologies that involve curriculum, learning environments, professional development and teacher adoption (Skaza, Crippen, \& Carroll, 2013). However, very few teachers have the competencies and the confidence in their abilities to become designers (Yael, Susan, \& Ornit, 2015). In addition, teachers are not familiar with engineering content or processes (Nadelson et al., 2013).

There is a growing consensus that science, technology, engineering and mathematics (STEM) education requires more integrated and interdisciplinary approaches to learning and skills development (Wu, Hu, \& Wang, 2019). The professional development received by the STEM HS learning coaches focused on PBL as a combination of curriculum organization and instructional strategy to produce a "minds-on, hands-on" learning experience by engaging students as stakeholders (L. \& E., 2016).

\section{B. Project-based teaching or learning}

Empirical studies have proved that IPBL can help students to develop knowledge management processes, arouse their interest and motivation in the subject course, foster their involvement in the learning process, and increase the level of cognition and satisfaction with learning outcomes (Dong \& He, 2019; Dekhane \& Tsoi, 2010; Yueh, Liu, \& Lin, 2015). This demonstrating the need, relevance and importance of interdisciplinary integration through IPBL in current pedagogical methodologies. Due to the multidimensional nature of students' competence, in order to enhance students' abilities, teachers must adjust their instruction based on the students' project competences (Lin, 2018). Very little research has explicitly examined project-based learning $(\mathrm{PjBL})$ as a pedagogical framework for teaching interdisciplinary STEM subjects. Actually, many of the learning experiences advocated in STEM teaching approaches are similar to the underlying principles of PjBL. Hence, PjBL in STEM (or STEM-PjBL approach) has promise as a framework for STEM initiatives (Siew, Amir, \& Chong, 2015). Moreover, as students engage with the STEM-PjBL approach, they are in essence mirroring the processes used by scientists and engineers to solve real-world issues through the active construction of new knowledge and the development of problem-solving skills(Flores, Knaupp, Middleton, \& Staley, 2002); (Eric, 2003);(Chris \& Merredith, 2004). The use of a STEM-PjBL could address some of these concerns in motivating students to learn science (Elkind, 1999). Ideas from educators have shown that the use of projects that kindles interest in students does make a difference in motivating them to be interested in doing the projects (Amir, 2014); (Marjaana, 2010); (Lan, 2011); (Meyer, 2012); (Mitchel, Robbie, \& Michael, 2000).

The advantages of PBL include integrating learning and real life, increasing learning motivation, and improving problemsolving skills (Cesar \& Arturo, 2010). Learners have more opportunities to interact with peers and may gain more from project work (Shih \& Tsai, 2017). In PBL, students should search more in the problem-space of authentic problems. With real problem solving as task drive, the application and acquirement of knowledge is to cultivate the students' problemsolving ability, composite thinking and creative thinking. 


\section{Flanders interaction analysis system and improved Flanders interaction analysis system}

Flanders interaction analysis (FIAS) is an observation technique used to record and analyze the process and influence of language interaction between teachers and students in the classroom. It was developed in the 1950s by Flanders and his collaborators at the University of Minnesota. Later, some researchers proposed the improved Flanders Interactive Analysis System (iFIAS)(Fang, Gao, \& Chen, 2012) based on FIAS.

The coding system of FIAS is divided into three categories: Teachers' speech acts, students' speech acts and silence, including 10 kinds of interactive behavior codes, and it also clarified the steps of coding in classroom teaching, and decoding, analyzing and presenting the data. Seen as one of the most famous techniques for studying classroom life, it was often used to help teachers to understand their own teaching methods and improve their own language styles.

The iFIAS complements the analysis of silence, behavior details and technology application, which was more suitable for modern classroom supported by analytical technology. The analysis system of iFIAS includes 14 behaviors: (1) Teacher accepting feelings, meaning that teacher accepts or clarifies students' attitude or feelings by a no threatening way; (2) Teacher praising or encouraging, meaning the actions or behaviors that teacher praises or encourages students; (3) Teacher using ideas of students, including recognizing the students' statements, modifying or restating the students' statements, applying the students' ideas to solve problems, comparing with other students' statements, and summarizing what the students have said; (4) Teacher asking questions, meaning asking the students questions and looking forward to their answer based on the teacher's opinions or ideas, including asking open questions or closed questions; (5)Teacher's lecture, including providing facts or opinions on the content, expressing teachers' own ideas, putting forward teachers' own explanations, or quoting the opinions of some authority (not students); (6) Teacher giving directions, meaning commanding or instructing students to do something, having the function of expecting students to obey; (7) Teacher criticizing, meaning that the content of the teacher's statement is to try to change the behavior of students, including scolding students; (8) Student talk-response passively, meaning that teachers designate students to respond, either to initiate students to speak, or to construct a dialogue situation, and the freedom of students to express their ideas is limited; (9) Student talk-initiation, meaning that students' answers go beyond the answers to the questions and express their own ideas, initiate new speech response (active response) topics, freely express their own opinions and ideas, such as putting forward thoughtful questions, open and active questions, free expression of their own opinions, including active questioning and active response; (10) Students discussing with their partners, meaning that students discuss or communicate some topics with their peers; (11) Useless confusion, meaning a brief pause, silence, or confusion so that the observer cannot understand the communication between teachers and students; (12) Useful silence, meaning that students are thinking or doing exercise in class; (13) Teacher manipulating technology, meaning that teachers use technology to present teaching content and explain viewpoint; (14) Student manipulating technology, meaning that students use technology to present the learning content and explain their views, or do experiments in class. The improved Flanders Interactive Analysis System is suitable for interactive behaviors analysis in modern class, which would be used in this research as the analytical framework.

\section{Method}

\section{A. Participants}

The main elements of this experiment include all the teachers who have received training and the main lecturers who have implemented the training. The research object is the whole teacher workshop process, and the training courses are mainly STEM courses. The whole training process lasted about 11 hours in total, and was divided into two days of four half-day lectures, each of which lasted about 3 hours. The teachers are between 35 and 60 years old and come from all over the country (about half of them from Beijing). They already have the foundation of information technology knowledge.

\section{B. Materials}

The software used in the training course is Mixly, an open-source graphical programming software for primary and secondary school maker education (creative electronics) developed by the maker lab of the education department of Beijing normal university. It replaces complex text editing with intuitive stacking of graphical blocks, and has the advantages of simple entry, easy to use, powerful functions, wide application and easy to expand. The software synchronizes the code in real time. In other words, if you put blocks on the left side, the code that have the same effect will appear on the right side. It is very convenient for beginners to learn the code.

\section{Instructional content}

The instructional content mainly containing the design and practice of algorithm, divided into the following several modules: mood barometer, LED lights, buzzer, breathing RGB lights, balancing instrument, digital bomb, hand speed measuring instrument, Internet, etc. In the course of these modules, we will introduce some basic knowledge of the program, such as for loop, selection structure (if $\cdots$ else, while), and so on. These modules contain the knowledge about 
technology and mathematics, some of them still involve the knowledge of engineering and art.

The training is product-oriented, and its teaching implementation and evaluation process all revolve around the product. In this process, the instructor will first show you the name and goal of the project, then teach some knowledge about the project, and then let the learners try to make it. In the production process, learners spontaneously formed a team to discuss the difficulties they encountered and their own experience, and interacted with teachers or teaching assistants when the discussion was not clear. Learners need to think about the project as a whole and grasp the relationship between various sub-parts, which will also stimulate their innovative thinking. This process helps learners to systematize a series of fragmentary knowledge and form systematic thinking. Finally, after the completion of the project, the teacher will give an oral evaluation of the completion of the project.

\section{Design, procedure and approach}

During the training, we recorded videos to analyze the training effect in the later stage. The videos can record the complete classroom teaching situation in the form of video, especially can capture the interactive behavior events such as teachers' and learners' speech and gesture in the classroom. The video of the training course is the content of analysis in this study. Content analysis, an objective and systematic research method to quantify and describe the obvious dissemination content(Fang, Gao, \& Chen, 2012) was used in the analysis stage.

The research approach and the analysis system was the improved Flanders Interactive Analysis System (iFIAS)(Fang et al., 2012), shown as Table 1.

Table 1. improved Flanders interactive analysis system

\begin{tabular}{|c|c|c|}
\hline object & code & Interactive behavior \\
\hline \multirow{8}{*}{ Teacher } & 1 & Accept feelings \\
\hline & 2 & Praise or encourage \\
\hline & 3 & Use the ideas of students \\
\hline & 4 & \multirow{2}{*}{ Ask question } \\
\hline & & \\
\hline & 5 & Lecture \\
\hline & 6 & Give direction \\
\hline & 7 & Criticize \\
\hline \multirow{4}{*}{ Student } & 8 & Talk-response passively \\
\hline & 0 & \multirow{2}{*}{ Talk initiation } \\
\hline & 9 & \\
\hline & 10 & Discuss with their partners \\
\hline \multirow{2}{*}{ Silence } & 11 & Useless confusion \\
\hline & 12 & Useful silence \\
\hline \multirow{2}{*}{ Technology } & 13 & Teacher manipulating technology \\
\hline & 14 & Students manipulating technology \\
\hline
\end{tabular}

Based on the coding table of iFIAS, we classified and counted the information content in a systematic, objective and quantitative way, and made a narrative description according to the statistics of category items. The auxiliary analysis tool of iFIAS had been developed, so the analysis process became simpler. Every three seconds, the verbal statements between teacher and students were classified into one of these 14 categories. Each observation was registered using time line as the $\mathrm{x}$-axis and iFIAS categories as the $\mathrm{y}$-axis in a spreadsheet. Then the total number of observations in each category and the total for the lessons were computed.

\section{Results}

\section{A. Statistics of the structure of the classroom}

As mentioned before, during the training, we recorded using video equipment. The frequency of interaction and other behaviors in the video is counted every 3 seconds and the ratio is calculated to obtain a statistical table. The data in the interactive analysis matrix of the whole training process were sorted out, and the frequency and proportion of all behaviors from behavior 1 to behavior 14 were counted, and table 2 was obtained. 
Table 2. Statistical table of classroom interaction

\begin{tabular}{|c|c|c|c|c|c|}
\hline sequence number & \multicolumn{3}{|c|}{ variables } & frequency & ratio \\
\hline 1 & \multicolumn{3}{|c|}{ Teacher accepts feelings } & 277 & $1.1798 \%$ \\
\hline 2 & \multicolumn{3}{|c|}{ Teacher praises or encourages } & 12 & $0.0511 \%$ \\
\hline 3 & \multicolumn{3}{|c|}{ Teacher uses the ideas of students } & 1388 & $5.9117 \%$ \\
\hline \multirow{2}{*}{4} & \multirow{2}{*}{$\begin{array}{c}\text { Teacher asks } \\
\text { question }\end{array}$} & 4.1 & Open-ended question & 34 & $0.1448 \%$ \\
\hline & & 4.2 & Closed question & 74 & $0.3152 \%$ \\
\hline 5 & \multicolumn{3}{|c|}{ Teacher lectures } & 5108 & $21.7556 \%$ \\
\hline 6 & \multicolumn{3}{|c|}{ Teacher gives direction } & 179 & $0.7624 \%$ \\
\hline 7 & \multicolumn{3}{|c|}{ Teacher criticizes or defends the their authority } & 0 & $0.0000 \%$ \\
\hline 8 & \multicolumn{3}{|c|}{ Students talk-response passively } & 56 & $0.2385 \%$ \\
\hline \multirow{2}{*}{9} & \multirow{2}{*}{$\begin{array}{l}\text { Students talk } \\
\text { initiation }\end{array}$} & 9.1 & Response actively & 868 & $3.6969 \%$ \\
\hline & & 9.2 & Question actively & 1360 & $5.7924 \%$ \\
\hline 10 & \multicolumn{3}{|c|}{ Students discuss with their partners } & 4889 & $20.8229 \%$ \\
\hline 11 & \multicolumn{3}{|c|}{ Useless confusion } & 344 & $1.4651 \%$ \\
\hline 12 & \multicolumn{3}{|c|}{ Useful silence } & 3005 & $12.7987 \%$ \\
\hline 13 & \multicolumn{3}{|c|}{ Teacher manipulates technique } & 2763 & $11.7680 \%$ \\
\hline 14 & \multicolumn{3}{|c|}{ Students manipulate technique } & 3122 & $13.2970 \%$ \\
\hline
\end{tabular}

The classroom structure of this training can be obtained from the statistical table of classroom teaching interaction shown in table 2. It can be seen from the data that the rates of teachers' speech, students' speech, silence, confusion and the use of technology are about $30.12 \%, 30.55 \%, 12.80 \%, 1.47 \%$ and $25.07 \%$ respectively (rounded to two decimal places). In this training, the ratio of teachers' speech and students' speech is about 1:1, which indicates that the learners have a high degree of speech participation.

The total ratio of teachers accepting feelings, praising and encouraging, using students' ideas and asking questions is $7.60 \%$. Positive interaction between the teacher and learners could be seen from it.

The silence rate that is beneficial to teaching is about $12.80 \%$, which is mainly reflected in students thinking about the teacher's questions and doing practical exercises. In this way, it can be found that the classroom of teacher training is very efficient, and people seldom hesitate and do more things. In the classroom, the rate of learners' talking-initiation is about $9.49 \%$, in which the learners' active response accounts for 3.70\%, the learners' talk-initiation accounts for $5.79 \%$, which accounts for almost one third of the learners' speech, indicating that the learners actively interact with the lecturers in class and are enthusiastic in learning. In addition, the discussion of information technology teachers in primary and secondary schools accounts for $20.82 \%$, which is equivalent to two thirds of the whole students' speech. It can be seen that the teachers who receive training are almost actively engaged in the training, with little difference in thinking and positive learning attitude. In addition, the ratio of learners' manipulating technique accounts for $13.27 \%$, indicating that teachers have reserved some time and space for learners to conduct experiments and practices. The fraction of useless confusion is actually just some communication before or after class. The useless confusion in class is actually a smaller part, so we won't analyze this part any more.

\section{B. The interactive analysis matrix}

According to the sequence of teacher's and students' behaviors, the sheet was converted into an interactive analysis matrix, as shown in table 3 (an example of the 1-hour class randomly selected from the whole training process). The method of obtaining this table is to form an order pair with the previous code and the last code respectively according to the code obtained from observation records, and count all the order pairs to obtain the migration matrix. The cells on the left diagonal of the matrix table are called "steady state cells", and the data falling on these cells indicates that a certain behavior has occurred for more than 3 seconds, that is, something has been done continuously. In table 3 , the steady state grid 1-1, 2-2, 4-4, 5-5, 6-6, 9-9, 10-10, 12-12, 13-13 all have data, they respectively represent the teacher continue to accept emotions, teacher praises learners, teacher continues to ask questions, teacher continues to teaching, teacher continues to issue instructions, learners continue to actively to answer the question, learners continue to discuss, the silence that conducive to teach, teacher continues to manipulate technology. 
Table 3. Video interactive analysis matrix (one part)

\begin{tabular}{|l|l|l|l|l|l|l|l|l|l|l|l|l|l|r|r|}
\hline category & 1 & 2 & 3 & 4 & 5 & 6 & 7 & 8 & 9 & 10 & 11 & 12 & 13 & 14 & sum \\
\hline 1 & & & & & & & & & & 1 & & 3 & & & 6 \\
\hline 2 & & & & & & & & & & 2 & & 2 & & & 5 \\
\hline 3 & & & & & 2 & & & & 1 & 2 & & 4 & & & 14 \\
\hline 4 & & & & 2 & 2 & 2 & & & 14 & 1 & & 18 & 25 & & 330 \\
\hline 5 & & & & & & & & & 1 & & & 4 & 3 & & 15 \\
\hline 6 & & & & & & & & & & & & & & & 0 \\
\hline 7 & & & & & & & & & & & & & & & 0 \\
\hline 8 & 1 & 2 & & 2 & 1 & 1 & & & 6 & 183 & & 25 & 1 & & 222 \\
\hline 9 & & & & & & & & & & & & & & & 0 \\
\hline 10 & 2 & & & 3 & 15 & 5 & & & 6 & 26 & & 4 & & & 462 \\
\hline 11 & & & & 1 & 23 & 2 & & & & 1 & & 2 & 5 & & 68 \\
\hline 12 & & & & & & & & & & & & & & & 0 \\
\hline 13 & 5 & 3 & 0 & 14 & 327 & 17 & 0 & 0 & 60 & 221 & 0 & 464 & 68 & 0 & 1179 \\
\hline 14 & & & & & & & & & & & & & & & \\
\hline
\end{tabular}

The interactive analysis matrix can reflect the emotional relationship between the teacher and the students. The intersection of 1-3 rows and 1-3 columns of the matrix is the "positive integration field", which can reflect the degree of emotional harmony between the teacher and students. The more data in the positive integration field, the better the relationship between the teacher and students. By contrast, 7-8 columns with 6-7 rows intersection area is the " defective domain", reflects the degree of emotional gap between the teacher and students. Data falling in this area shows that communication between the teacher and learners is not well, so the more defective domain data, suggests that the more serious the gap between the teacher and students. According to table 3, it can be seen that the teacher accepting the emotion of learners appeared twice. The number of the teacher praising learners is 1, and the number of criticism and instruction issued by the teacher in the defective field is 0 . This shows that there is no serious gap between teachers and learners in this course training, and the communication is harmonious.

The innovation degree of teacher's questions can also be observed through interactive analysis matrix. Code 4 represents the teacher's question and code 8 the learner's response. The closed loop formed by four cells: 4-4, 4-8, 8-4 and 8-8, represents the degree of "training-type question". The closed loop formed by the four cells of 3-3, 3-9, 9-3, 9-9, and another three cells of 10-3,10-10,3-10 which are composed of the teacher's acceptance of the advice of code 3 and the learners' active response of code 9, represents the degree of "innovative question". By comparing the "training-type questioning" loop with the "innovative questioning" loop, it can be seen that the total data of the former is 9 , while the total data of the latter is 268 . Through the comparison, it can be seen that the degree of "innovative questioning" of the teacher is much higher than that of "training-type questioning". This indicates that the situation in which the teacher asks questions to guide the learners to use or adopt the learner's ideas is much better than that in which the teacher asks questions to drive the learners to answer the questions. It also shows that the teacher's success in this course triggers learners to interact and think actively with the teacher.

In addition, 10-10 cell on the diagonal represents the number of continuous discussions the learners have, the number of which is large; 12-12 cell is conducive to more times of thinking in teaching, which also indicates that in STEM courses of algorithm, the teacher gives learners sufficient time to think. 13-13 cell is the continuous manipulation of technology by the teacher, indicating that the teacher use information technology to teach. 
Table 4. Question and answer pattern ordered pairs and meaning

\begin{tabular}{|c|c|c|}
\hline $\begin{array}{l}\text { Special } \\
\text { ordered pairs }\end{array}$ & Ordered pairs & meaning \\
\hline $\begin{array}{l}\text { steady state } \\
\text { cells }\end{array}$ & $\begin{array}{c}(1,1)(2,2)(3,3)(4,4)(5,5)(6,6)(7,7)(8,8) \\
(9,9)(10,10)(11,11)(12,12)(13,13) \\
(14,14)\end{array}$ & $\begin{array}{l}\text { A certain behavior has occurred for more } \\
\text { than } 3 \text { seconds, that is something has been } \\
\text { done continuously. }\end{array}$ \\
\hline $\begin{array}{l}\text { positive } \\
\text { integration } \\
\text { field }\end{array}$ & $\begin{array}{c}(1,1)(1,2)(1,3)(2,1)(2,2)(2,3)(3,1)(3,2) \\
(3,3)\end{array}$ & $\begin{array}{l}\text { The degree of emotional harmony between } \\
\text { the teacher and students. }\end{array}$ \\
\hline $\begin{array}{l}\text { defective } \\
\text { domain }\end{array}$ & $(7,6)(7,7)(8,6)(8,7)$ & $\begin{array}{l}\text { The degree of emotional gap between the } \\
\text { teacher and students. }\end{array}$ \\
\hline $\begin{array}{l}\text { training-type } \\
\text { question }\end{array}$ & $\begin{array}{l}(4,4)(4,5)(4,6)(4,7)(4,8)(5,8)(6,8)(7,8) \\
(8,8)(8,7)(8,6)(8,5)(8,4)(7,4)(6,4)(5,4)\end{array}$ & $\begin{array}{l}\text { The degree of students to answer the } \\
\text { questions driven by teacher's asking. }\end{array}$ \\
\hline $\begin{array}{l}\text { innovative } \\
\text { question }\end{array}$ & $\begin{array}{c}(3,3)(3,4)(3,5)(3,6)(3,7)(3,8)(3,9)(4,9) \\
(5,9)(6,9)(7,9)(8,9)(9,9)(9,8)(9,7)(9,6) \\
(9,5)(9,4)(9,3)(8,3)(7,3)(6,3)(5,3)(4,3) \\
(3,10)(4,10)(5,10)(6,10)(7,10)(8,10) \\
(9,10)(10,10)(10,9)(10,8)(10,7)(10,6) \\
(10,5)(10,4)(10,3)\end{array}$ & $\begin{array}{l}\text { The degree of student speaking out on his } \\
\text { or her own initiative as a result of the } \\
\text { teacher's guidance, acceptance, or adoption } \\
\text { of the student's opinion. }\end{array}$ \\
\hline
\end{tabular}

\section{The comparison of behaviors between teachers and learners}

According to the meanings of the codes in the original iFIAS interactive analysis table, the statistical data in the interactive analysis migration matrix, the iFIAS teaching behavior variable scale was integrated and obtained (table 5).

Table 5. Teaching behavior variable scale

\begin{tabular}{|c|c|c|}
\hline Content of analysis & Computational formula & Implication \\
\hline Teacher's speech ratio & $\begin{array}{c}\text { The number of times from } \\
\text { column } 1 \text { to column } 7 \text { / the total } \\
\text { number of times }\end{array}$ & The proportion of the teacher's speech in the classroom. \\
\hline Students' speech ratio & $\begin{array}{l}\text { The number of times from } \\
\text { column } 8 \text { to column } 10 / \text { the } \\
\text { total number of times }\end{array}$ & $\begin{array}{l}\text { The proportion of students' sp } \\
\text { is the student participation ra }\end{array}$ \\
\hline Useful silence ratio & $\begin{array}{l}\text { The number of times of column } \\
12 \text { / the total number of times }\end{array}$ & $\begin{array}{l}\text { The proportion of the conducive silence, such as } \\
\text { practice, thinking and so on. }\end{array}$ \\
\hline $\begin{array}{l}\text { The proportion of } \\
\text { teacher's indirect } \\
\text { influence and direct } \\
\text { influence }\end{array}$ & $\begin{array}{l}\text { The number of times from } \\
\text { column } 1 \text { to column } 4 \text { / the } \\
\text { number of times from column } 5 \\
\text { to column } 7\end{array}$ & $\begin{array}{l}\text { If the ratio is greater than } 1 \text {, teachers tend to have } \\
\text { indirect control over the classroom and students. On the } \\
\text { contrary, teachers tend to direct control. }\end{array}$ \\
\hline $\begin{array}{l}\text { The proportion of } \\
\text { teachers positive } \\
\text { influence and negative } \\
\text { influence }\end{array}$ & $\begin{array}{l}\text { The number of times from } \\
\text { column } 1 \text { to column } 3 \text { / the } \\
\text { number of times from column } 6 \\
\text { to column } 7\end{array}$ & $\begin{array}{l}\text { If the ratio is greater than } 1 \text {, it indicates that teachers pay } \\
\text { attention to exert positive reinforcement on students. On } \\
\text { the contrary, it means that teachers pay attention to exert } \\
\text { negative reinforcement on students. }\end{array}$ \\
\hline
\end{tabular}

It can be seen that the proportion of the teacher's language is $31.04 \%$ (the data is obtained after rounding and retaining two decimal places) in table 6 and the proportion of learners' speech in class is $23.83 \%$. In addition, the silence (thinking and practice) that is conducive to teaching occupies $39.36 \%$ of this class, while there is almost no useless confusion in the class. Therefore, the teacher in this training class respects the independent subject identity of learners, leaving enough time for learners to think, explore and practice. The proportion of the teacher's indirect influence and direct influence is $6.4 \%$, which is far less than 1 , indicating that teachers tend to directly control learners. The proportion of teachers' positive influence and negative influence is $47.06 \%$, which is less than 1 . When we see codes $1,2,3,6$ and 7 , we can find that 
there is a relatively large amount of data in code 6 . However, when we look back at the video, we find that most of the instructions of the teacher are to let students think and practice before teaching, which should be regarded as a guide to learners rather than a negative command. Therefore, the positive influence of teachers is greater than the negative influence.

Table 6. Interactive analysis migration matrix analysis formula and statistical ratio

\begin{tabular}{|c|c|c|}
\hline Content of analysis & Computational formula & $\begin{array}{l}\text { Ratio (round to two } \\
\text { decimal places) }\end{array}$ \\
\hline Teacher's speech ratio & $\begin{array}{l}\text { The number of times from column } \\
1 \text { to column } 7 \text { / the total number of } \\
\text { times }\end{array}$ & $31.04 \%$ \\
\hline Students' speech ratio & $\begin{array}{l}\text { The number of times from column } \\
8 \text { to column } 10 / \text { the total number } \\
\text { of times }\end{array}$ & $23.83 \%$ \\
\hline Useful silence ratio & $\begin{array}{l}\text { The number of times of column } 12 \\
\text { / the total number of times }\end{array}$ & $39.36 \%$ \\
\hline $\begin{array}{l}\text { The proportion of teacher's } \\
\text { indirect influence and direct } \\
\text { influence }\end{array}$ & $\begin{array}{l}\text { The number of times from column } \\
1 \text { to column } 4 / \text { the number of } \\
\text { times from column } 5 \text { to column } 7\end{array}$ & $6.40 \%$ \\
\hline $\begin{array}{l}\text { The proportion of teachers' } \\
\text { positive influence and } \\
\text { negative influence }\end{array}$ & $\begin{array}{l}\text { The number of times from column } \\
1 \text { to column } 3 / \text { the number of } \\
\text { times from column } 6 \text { to column } 7\end{array}$ & $47.06 \%$ \\
\hline
\end{tabular}

D. Works/products validation

At the end of the course, we ask participants to submit their work or results and the work is to design a set of machines that can do this: the buzzer will sound when the hand presses the speedometer more than 40 times per minute, and you should register and enable the Internet of Things. After review, the error rate in the programming of these exercises or results is low, indicating that peer discussion or group discussion plays an important role in the process of practice. Only a small number of errors occur because incomplete understanding of the mission's objectives. In addition, at the end of the workshop, learners are also very active trainers to communicate, until they get the knowledge or answers they want to leave satisfied. In addition, we found that students can achieve the same effect in many different ways. It shows that the creativity of the learners is brought into full play.

\section{Discussion}

\section{A. Questioning behavior}

As the results shown, the ratio of closed questions to open questions proposed by the teacher is about 7:3. Previous research has found that the best ratio of closed questions and open questions is 7:3 when the level of behavioral complexity emphasized in class is low. When the complexity level is high, the optimal ratio of the two is 6:4 (Gu \& Wang, 2004).In this class on the STEM of teacher training, learners need hands-on practice, often use its related parts to make small lights, buzzer, etc., which also requires thinking for algorithm design, and is often spontaneous discussion between partners, so the complexity of process and the teaching content is higher, the teacher ask closed questions about 7:3 than open questions, close to the best ratio of $6: 4$, conform to the requirements of the training.

In fact, questioning can be used to achieve a broader purpose in classroom teaching according to previous studies. For students, questioning can recall the materials read or learned before; diagnose students' ability, attitude and tendency; encourage students' critical and creative thinking; arouse students' interest in the subject; encourage students' reflection and discussion on the problem(Wilen, Ishler, Hutchison, \& Kindsvatter, 2000). For teachers, questioning can help them to investigate students' thinking; evaluate learning progress; manage and control students' behavior (Wilen, Ishler, Hutchison, \& Kindsvatter, 2000). In the training course in this study, a total of 108 questioning behaviors of the teacher were counted, which played an indelible role in the success of teaching, especially for leading the discussion between students. Through effective questioning, students' interests were stimulated, and the classroom atmosphere was mobilized.

Youru Xie et al. (2013) conducted a study on the teaching characteristics and teacher-student behavior of the excellent video open courses of modern etiquette, mathematical culture and human anatomy- Comparing the analysis results of their excellent courses with the analysis results of this training, it can be found that the lowest proportion of teachers' speech in the former is $51.6 \%$, which is still 2.5 times higher than the proportion of teachers' speech in the latter. The 
students of the former had the highest speech rate of $2.7 \%$, while the students of the latter accounted for $30.6 \%$, which was 15 times higher than the former. This shows that the participation rate of learners in STEM training is very high, and both teacher-student interaction and student-student interaction are more and deeper than in the former. In this training, teachers do not focus on implanting knowledge and ignore students' knowledge building process as in traditional classes. In addition, the former teacher asked more questions than the latter.

\begin{tabular}{|c|c|c|c|c|}
\hline \multicolumn{5}{|c|}{ Statistics of Teacher-student Behavior Ratio in Three Classes } \\
\hline \multirow{5}{*}{$\begin{array}{l}\text { Teacher-student } \\
\text { behavior ratio }\end{array}$} & & & ratio & \\
\hline & Variables & $\begin{array}{l}\text { Modern } \\
\text { etiquette }\end{array}$ & $\begin{array}{c}\text { Mathematics } \\
\text { culture }\end{array}$ & $\begin{array}{l}\text { Human } \\
\text { anatomy }\end{array}$ \\
\hline & Teacher speech ratio & $76.30 \%$ & $86.50 \%$ & $51.60 \%$ \\
\hline & Student speech ratio & $7.30 \%$ & $9.80 \%$ & $2.70 \%$ \\
\hline & $\begin{array}{l}\text { Technology-based } \\
\text { interaction ratio }\end{array}$ & $16.10 \%$ & $2.80 \%$ & $45.70 \%$ \\
\hline \multirow{3}{*}{$\begin{array}{c}\text { Teacher question } \\
\text { ratio }\end{array}$} & Teacher question ratio & $5.90 \%$ & $13.30 \%$ & $6.20 \%$ \\
\hline & $\begin{array}{l}\text { Ratio of open questions } \\
\text { asked by teachers }\end{array}$ & $58.60 \%$ & $31.50 \%$ & $63.20 \%$ \\
\hline & $\begin{array}{l}\text { Ratio of close questions } \\
\text { asked by teachers }\end{array}$ & $41.40 \%$ & $68.50 \%$ & $36.80 \%$ \\
\hline
\end{tabular}

Figure 1. The teaching characteristics and the proportion of the behavior of teachers and students in the video course

Table 7. The ratio of all aspects of the whole training

\begin{tabular}{lr}
\hline \multicolumn{1}{c}{ category } & \multicolumn{1}{c}{ ratio } \\
\hline Teacher's speech & $23.0291 \%$ \\
Teacher's question & $0.4600 \%$ \\
Open question : closed question & $1: 2.18$ \\
Students' speech & $30.5507 \%$ \\
Useful silence & $12.7987 \%$ \\
Useless confusion & $1.4651 \%$ \\
Teacher manipulates technique & $11.7680 \%$ \\
Students manipulate technique & $13.2970 \%$ \\
Teacher's behavior & $34.7971 \%$ \\
Students' behavior & $43.8477 \%$ \\
\hline
\end{tabular}

Teachers should encourage students to share learning experience with each other in teaching activities, which can not only help meet with difficulties in the process of learners, and make learners clearly express their views and experiences will deepen learners understanding of the problem.

\section{B. The full application of the dominant - subject principle}

In an excellent class, the teacher must fully respect the learner's personality and the learner's dominant position as the originator of the action of learning. Teachers cannot manipulate learners like a puppet, they should give learners a certain amount of freedom, let learners actively explore their own and questions. The teacher should be a leader of the teaching objectives, the controller of the teaching process, the evaluator of the learning results, and the friend of the learners(Duffy \& Jonassen,2013).

Although in mainland China, we can see that teachers in many districts (such as Beijing and Shenzhen) are able to guide students to discuss problems very well, there are also many school teachers in other districts who pay little attention to students' own understanding and discussion and only focus on completing the course content to complete the teaching task. We need to tell the teachers that they need to lead the students in topic discussions properly in class, because it helps the students' knowledge understanding and knowledge construction. Based on this experiment, we mainly discuss how to 
guide learners (subjects) in class discussion when the teacher is the dominant role. The teacher should guide the learners in the discussion. One part of discussion is about the possible solutions, the other part of discussion is about the feasibility of these schemes discussed. Learners may have different ways of understanding a given problem, and we don't know if they really understand the problem. Another discussion on the key issues could be organized to help learners have profound perspective.

\section{Interaction between learners}

It is worth noting that in this training course, the proportion of learners' discussion is very large, reaching more than $20 \%$, showing that there were many opportunities for communication and interaction between learners in this course. By analyzing the video content of the course, the researcher found that most of the parts of discussion between learners and peers were about the understanding of key problems, possible solutions to the problems, and the feasibility of the solutions. From such a large proportion of discussion, we can see that the main position of learners is very obvious, usually considered as a good phenomenon. However, the analysis of video content shows that sometimes the learners' understanding of the problem deviated, which leads to inaccurate discussion direction. In addition, after the discussion, there was a lack of presentation and reporting links, and learners do not have the opportunity to express their views, which makes the effect of the discussion links between learners greatly reduced. Penny (1996) proposed that the teacher should make a detailed description and demonstration before the group discussion activity, conduct patrol guidance during the activity, summarize in the whole class after the end, and give some feedback to the learners.

\section{Conclusion}

From the results submitted by learners, it can be seen that their creativity has been explored to a certain extent. In addition, from the beginning to the end of the course, learners communicate with each other, and many knowledge blind spots are cleared up, so that all aspects of knowledge can be integrated.

In project-based STEM training, teachers and students work together to complete the project and make progress together. Learners' cognitive abilities were improved during STEM training, and the frequent interaction between learners and others, students' enthusiasm and initiative in learning was high. The interaction between teachers and students, as well as between students and students, is much richer than in the traditional interaction in STEM courses. In addition, the relationship between teachers and students is positive and the students are not emotionally disharmonious with the teachers. All of these indicate that the project-based STEM course's ecology has reached a higher level and has been continuously maintained and deepened.

In addition, the more the order of training project, the more the learners use the knowledge they have learned, which indicates that they have carried out the application of knowledge migration and they have developed cognitive abilities such as comparison, analysis and synthesis ability which are the reflection of interdisciplinary ability. Moreover, their knowledge transfer ability is more flexible.

However, iFIAS can only analyze the classroom teaching situation through the verbal interaction between teachers and students as well as teaching and learning behaviors, but it cannot observe the non-verbal behaviors (e.g. eye-contact), which inevitably produces errors in the analysis results, so it cannot fully and truly reflect the classroom situation, and cannot reflect the meaning structure of higher educational activities.

Although the teacher training has achieved remarkable results, it only shows that the learners themselves have absorbed a lot of knowledge. We are not sure how effective these teachers are in teaching in primary and secondary schools, but at least this is the first step in improving the ability of primary and secondary learners to solve problems across disciplines -- the development of teachers' professional skills. At present, school education in China is still based on subject classification and subject as independent knowledge system. Although it can cultivate talents with solid foundation, it is not conducive to the cultivation of innovative talents, resulting in the scarcity of STEM education talents who adapt to the innovative situation. STEM courses require teachers to have strong discipline knowledge reserve, high innovation, practical ability, multiple intelligences, humanities and Art Literacy, so it is necessary for teachers to receive training to master new knowledge and skills, have the ability to integrate multiple disciplines, and understand the latest development trend in the field. In the future, we still need to continue to explore, discover and improve teacher professional development and classroom instructional design. In the future, when conducting workshops or trainings related to teacher professional development, I suggest that scholars pay more attention to the teaching design of the training content, and more importantly, cultivate teachers' interdisciplinary knowledge transferring ability. Teachers are important persons to spread knowledge to students who will subtly apply their existing knowledge to teaching work after all.

\section{Acknowledgement}

The work described in this paper was fully supported by a grant from the National Natural Science Foundation of China (Grant Number 61977009). 


\section{References}

Amir, N. (2014). Showcasing the creative talents in science of the academically less- inclined students through a valuesdriven toy storytelling project. IGI Global Publishing, 141-179. https://doi.org/10.4018/978-1-4666-6489-0.ch007

Cesar, D., \& Arturo, J. (2010). Database Design Learning: A Project-Based Approach Organized through a Course Management System. Computers \& Education, 3(55), 1312-1320. https://doi.org/10.1016/j.compedu.2010.06.001

Chris, R., \& Merredith, P. (2004). Bringing engineering to elementary school. Journal of STEM Education: Innovations and Research, 3-4(5), 17-28.

Conradty, C., Sotiriou, S. A., \& Bogner, F. X. (2020). How Creativity in STEAM Modules Intervenes with Self-Efficacy and Motivation. EDUCATION SCIENCES, 10(703). https://doi.org/10.3390/educsci10030070

Dekhane, S., \& Tsoi, M. Y. (2010). Work in progress - Inter-disciplinary collaboration for a meaningful experience in a software development course. Paper presented at the Proceedings-Frontiers in Education Conference, FIE. https://doi.org/10.1109/FIE.2010.5673103

Dong, Y., \& He, J. (2019). Application of PBL Project-based Learning in University Teaching. Modern Educational Technology, 9(29), 53-58.

Drake, S. M. (1993). Planning Integrated Curriculum: The Call to Adventure. Association for Supervision and Curriculum Development

Duffy, T. M., \& Jonassen, D. H. (2013). Constructivism and the technology of instruction: A conversation. Constructivism and the Technology of Instruction: A Conversation (pp. 1-221). Taylor and Francis. https://doi.org/10.4324/9780203461976

Elkind, D. (1999). Educators, scholars, and researchers in the United States: American Association for the Advancement of Science, Washington, DC.

Eric, G. (2003). Teaching and learning mathematics for social justice in an urban, Latino school. Journal for Research in Mathematics Education, 1(34), 37-73. https://doi.org/10.2307/30034699

Fang, H., Gao, C., \& Chen, J. (2012). Improved Flanders Interactive Analysis System and Its Application. China Electronic Education, (10), 109-113.

Flores, A., Knaupp, J., Middleton, J. A., \& Staley, F. A. (2002). Integration of technology, science, and mathematics in the middle grades: a teacher preparation program. Contemporary Issues in Technology and Teacher Education, (2), 31-39.

Gu, X., \& Wang, W. (2004). Support teachers' development with it-based interaction analysis system in class. China Electronic Education, (7), 18-21.

Honey, M., Pearson, G., \& Schweingruber, H. (2014). STEM Integration in K-12 Education: Status, Prospects, and an Agenda for Research.. Washington,DC: National Academies Press.

Hu, C., Yeh, H., \& Chen, N. (2020). Enhancing STEM competence by making electronic musical pencil for nonengineering students. Computers \& Education, 150, 103840. https://doi.org/10.1016/j.compedu.2020.103840

Khuyen, N. T. T., Van Bien, N., Lin, P. L., Lin, J., \& Chang, C. (2020). Measuring Teachers' Perceptions to Sustain STEM Education Development. Sustainability, 4(12), 1531-1546. https://doi.org/10.3390/su12041531

L., D. A., \& E., R. S. (2016). STEM High School Teachers' Views of Implementing PBL: An Investigation Using Anecdote Circles. Interdisciplinary Journal of Problem-based Learning, 7(11). https://doi.org/10.7771/1541-5015.1566

Lan, B. L. (2011). Design Projects in First-Year Physics. Latin-American Journal of Physics Education

Levin, T. (1999). The non linear curriculum The Innovative School: Organization and Instruction (115-146): Westport, CT: Greenwood. Reprinted.

Lin, C. L. (2018). The development of an instrument to measure the project competences of college students in online project-based learning. Journal of Science Education and Technology, (27), 57-69. https://doi.org/10.1007/s10956017-9708-y

Marjaana, K. (2010). Creative and playful learning: learning through game co-creation and games in a playful learning environment. Thinking Skills and Creativity, 1(5), 1-15. https://doi.org/10.1016/j.tsc.2009.11.001

Meyer, D. (2012). Science teacher (Normal, Ill.) (79), 58-62. https://doi.org/10.1177/000313131206200218

Mitchel, R., Robbie, B., \& Michael, E. (2000). Beyond Black Boxes: Bringing Transparency and Aesthetics Back to Scientific Investigation. Journal of the Learning Science, 1(9), 7-30. https://doi.org/10.1207/s15327809jls0901_3 
Nadelson, L. S., Callahan, J., Pyke, P., Hay, A., Dance, M., ... Pfiester, J. (2013). Teacher stem perception and preparation: inquiry-based stem professional development for elementary teachers. Journal of Educational Research, 2(106), 157-168. https://doi.org/10.1080/00220671.2012.667014

Nicolescu, B. (1997). The trans-disciplinary evolution of learning. Proceedings of the International Congress on What University for Tomorrow, 1-11.

Schmidt, M., \& Fulton, L. (2016). Transforming a traditional inquiry-based science unit into a stem unit for elementary pre-service teachers: a view from the trenches. Journal of Science Education and Technology, 2(25), 302-315. https://doi.org/10.1007/s10956-015-9594-0

Shih, W., \& Tsai, C. (2017). Students' perception of a flipped classroom approach to facilitating online project-based learning in marketing research courses. Australasian Journal of Educational Technology, 5(33), 32-49. https://doi.org/10.14742/ajet.2884

Siew, N. M., Amir, N., \& Chong, C. L. (2015). The perceptions of pre-service and in-service teachers regarding a projectbased STEM approach to teaching science. SpringerPlus, 8(4). https://doi.org/10.1186/2193-1801-4-8

Skaza, H., Crippen, K. J., \& Carroll, K. R. (2013). Teachers' barriers to introducing system dynamics in k-12 stem curriculum. System Dynamics Review, 3(29), 157-169. https://doi.org/10.1002/sdr.1500

Steffen, H., Janis, F., Rainer, M., \& Christoph, S. J. (2016). Gis teacher training: empirically-based indicators of effectiveness. Journal of Geography, 1(115), 12-23. https://doi.org/10.1080/00221341.2015.1016546

Ur, P. (1996). A Course in Language Teaching: Practice and Theory. Cambridge: Cambridge University Press.

Wilen, W., Ishler, M., Hutchison, J., \& Kindsvatter, R. (2000). Dynamics of Effective Teaching (4ed.): Addison Wesley Longman, Inc.

Wu, B., Hu, Y., \& Wang, M. (2019). Scaffolding design thinking in online stem preservice teacher training. British Journal of Educational Technology, 5(50), 2271-2287. https://doi.org/10.1111/bjet.12873

Xie, Y., \& Li, K. (2006). Foundation of Research Methods in Educational Technology. Beijing: Higher Education Press.

Xie, Y., Wang, Q., Peng, L., \& Li, G. (2013). Research on Teaching Characteristics and Teacher-student Behavior of Excellent Video Open Classes. E-education Research, 10(34), 90-96.

Yael, K., Susan, M., \& Ornit, S. (2015). Teachers as designers of technology enhanced learning. Instructional Science: $A n$ International Journal of the Learning Sciences, 2(43), 173-179. https://doi.org/10.1007/s11251-014-9343-4

Yueh, H., Liu, Y., \& Lin, W. (2015). Fostering interdisciplinary learning in a smart living technology course through a PBL approach. International Journal of Engineering Education, 1(31), 220-228.

\section{Copyrights}

Copyright for this article is retained by the author(s), with first publication rights granted to the journal.

This is an open-access article distributed under the terms and conditions of the Creative Commons Attribution license which permits unrestricted use, distribution, and reproduction in any medium, provided the original work is properly cited. 